\title{
Ivy and Neurogliaform Interneurons Are a Major Target of $\mu$-Opioid Receptor Modulation
}

\author{
Esther Krook-Magnuson, Lillian Luu, Sang-Hun Lee, Csaba Varga, and Ivan Soltesz \\ Department of Anatomy and Neurobiology, University of California, Irvine, California 92697-1280
}

$\mu$-0pioid receptors ( $\mu$ ORs) are selectively expressed on interneurons in area CA1 of the hippocampus. Fast-spiking, parvalbuminexpressing, basket cells express $\mu$ ORs, but circumstantial evidence suggests that another major, unidentified, GABAergic cell class must also be modulated by $\mu$ ORs. Here we report that the abundant, dendritically targeting, neurogliaform family of cells (Ivy and neurogliaform cells) is a previously unrecognized target of direct modulation by $\mu$ ORs. Ivy and neurogliaform cells are not only numerous but also have unique properties, including promiscuous gap junctions formed with various interneuronal subtypes, volume transmission, and the ability to produce a postsynaptic $\mathrm{GABA}_{\mathrm{B}}$ response after a single presynaptic spike. Using a mouse line expressing green fluorescent protein under the neuropeptide $Y$ promoter, we find that, across all layers of CA1, activation of $\mu$ ORs hyperpolarizes Ivy and neurogliaform cells. Furthermore, paired recordings between synaptically coupled Ivy and pyramidal cells show that Ivy cell terminals are dramatically inhibited by $\mu \mathrm{OR}$ activation. Effects in Ivy and neurogliaform cells are seen at similar concentrations of agonist as those producing inhibition in fast-spiking parvalbumin basket cells. We also report that Ivy cells display the recently described phenomenon of persistent firing, a state of continued firing in the absence of continued input, and that induction of persistent firing is inhibited by $\mu \mathrm{OR}$ activation. Together, these findings identify a major, previously unrecognized, target of $\mu \mathrm{OR}$ modulation. Given the prominence of this cell type in and beyond CA1, as well as its unique role in microcircuitry, opioid modulation of neurogliaform cells has wide implications.

\section{Introduction}

Opioids include endogenous opioids, as well as therapeutic agents and drugs of abuse, such as morphine and heroin. Acute and chronic opioid administration affects CA1 function and plasticity (Mansouri et al., 1997; Wagner et al., 2001), and the hippocampal $\mu$ opioid receptor ( $\mu \mathrm{OR}$ ) system is altered in epilepsy and Alzheimer's disease (Gall, 1988; Meilandt et al., 2008; Cuellar-Herrera et al., 2010).

In CA1, $\mu$ ORs are selectively expressed on interneurons (Drake and Milner, 1999), and activation of $\mu$ ORs thus disinhibits the network, altering CA1 integration of Schaffer collateral and temporo-ammonic inputs (McQuiston, 2011). It has been shown that $\mu$ ORs are expressed preferentially on perisomatically projecting interneurons (Svoboda et al., 1999), specifically parvalbumin (PV) positive, fast-spiking (FS), basket cells (Drake and Milner, 2002; Neu et al., 2007; Glickfeld et al., 2008). However, evidence suggests that another, unidentified class of interneurons must also express $\mu$ ORs. For example, in the presence of agatoxin, which blocks neurotransmission from PV basket cells

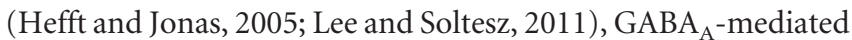

Received May 5, 2011; revised Aug. 16, 2011; accepted Aug. 20, 2011.

Author contributions: E.K.-M. and I.S. designed research; E.K.-M., S.-H.L., and C.V. performed research; E.K.-M., L.L., and S.-H.L. analyzed data; E.K.-M. and I.S. wrote the paper.

This work was supported by the George E. Hewitt Foundation for Medical Research (E.K.-M.), National Institutes of Health Grant NS35915 (I.S.), the Epilepsy Foundation (C.V.), and the Epilepsy Foundation through the generous support of the Eric W. Lothman Training Fellowship (S.-H.L.). We thank Rose Zhu for excellent technical assistance and support, Samantha Major for her assistance, and Dr.Stephen Ross for the generous loan of a Nikon FN-1 Eclipsemicroscope

Correspondence should be addressed to Esther Krook-Magnuson, Department of Anatomy and Neurobiology, University of California, Irvine, Irvine, CA 92697. E-mail: ekrookma@uci.edu.

DOI:10.1523/JNEUROSCI.2269-11.2011

Copyright $\odot 2011$ the authors $\quad 0270-6474 / 11 / 3114861-10 \$ 15.00 / 0$ inhibition remains $\mu$ OR sensitive (Lafourcade and Alger, 2008). Furthermore, the unidentified $\mu \mathrm{OR}$-expressing neurons are likely dendritically targeting, because $\mu \mathrm{OR}$ modulation of inhibition is seen in all layers of CA1 (McQuiston, 2008). A final clue as to the identity of this cell group is that $\mu \mathrm{OR}$ activation reduces $\mathrm{GABA}_{\mathrm{B}}$-mediated inhibition, even more so than it does $\mathrm{GABA}_{\mathrm{A}}$ (Lafourcade and Alger, 2008).

The only interneuron type shown to evoke a $\mathrm{GABA}_{\mathrm{B}}$-mediated response after a single presynaptic spike is the dendritically projecting neurogliaform cell (NGF) (Tamás et al., 2003). NGFs also uniquely produce a slow $\mathrm{GABA}_{\mathrm{A}}$ postsynaptic response, show volume transmission, and are connected by gap junctions to each other and other types of interneurons (Price et al., 2005; Simon et al., 2005; Zsiros and Maccaferri, 2005; Krook-Magnuson and Huntsman, 2007; Szabadics et al., 2007; Oláh et al., 2009; Armstrong et al., 2011). The thin axons of NGFs form a dense local plexus, and, in CA1, NGFs are often located at the border of the stratum lacunosummoleculare (SLM). NGFs receive excitatory input from both CA3 and entorhinal cortex and provide feedforward inhibition to local principal cells (for review, see Capogna, 2010).

Ivy cells are a closely related cell type; similar to NGFs, Ivy cells are late spiking, express neuropeptide Y (NPY), and have thin axons that form a dense local plexus (Fuentealba et al., 2008). Unlike NGFs, Ivy cells are located in or near stratum pyramidale (SP), target proximal (rather than distal) dendrites, and do not express reelin (Fuentealba et al., 2008, 2010). Together, Ivy and NGF cells are the most abundant interneuron class in CA1, comprising 37\% of GABAergic cells (Fuentealba et al., 2008), and are found throughout the hippocampal formation (Szabadics and Soltesz, 2009; Szabadics et al., 2010; Armstrong et al., 2011). 
Here we report that NGF and Ivy cells are a major, novel target of opioid modulation. $\mu$ ORs inhibit NGF and Ivy cells by activation of a hyperpolarizing current and nearly abolish neurotransmission from Ivy cells. Finally, we demonstrate that Ivy cells display persistent firing (Sheffield et al., 2011) and that induction of persistent firing is also inhibited by $\mu \mathrm{OR}$ activation.

\section{Materials and Methods}

Our experimental protocols were approved by the Institutional Animal Care and Use Committee of the University of California, Irvine.

Electrophysiological recordings. Transverse hippocampal slices were prepared from mice or Wistar rats (except when noted, postnatal day 19-36, both sexes) deeply anesthetized with isoflurane. Slices were prepared in ice-cold sucrose solution and incubated at $33^{\circ} \mathrm{C}$ for $1 \mathrm{~h}$ before being transferred to room temperature. The sucrose solution contained the following (in $\mathrm{mm}$ ): $85 \mathrm{NaCl}, 75$ sucrose, $2.5 \mathrm{KCl}, 25$ glucose, 1.25 $\mathrm{NaH}_{2} \mathrm{PO}_{4}, 4 \mathrm{MgCl}_{2}, 0.5 \mathrm{CaCl}_{2}$, and $24 \mathrm{NaHCO}_{3}$. All recordings were done at $36 \pm 0.5^{\circ} \mathrm{C}$ in artificial CSF (recording ACSF) containing the following (in $\mathrm{mm}$ ): $2.5 \mathrm{KCl}, 10$ glucose, $126 \mathrm{NaCl}, 1.25 \mathrm{NaH}_{2} \mathrm{PO}_{4}, 2$ $\mathrm{MgCl}_{2}, 2 \mathrm{CaCl}$, and $26 \mathrm{NaHCO}_{3}$. Slices were visualized with an upright microscope (Eclipse FN-1; Nikon) with infrared (750 nm) Nomarski differential interference contrast optics (Nikon $40 \times$ near-infrared Apo N2 NA0.8W WD3.5 objective with $1.5 \times$ magnification lens). This microscope was additionally equipped with a mercury or xenon lamp light source for epifluorescence. Recordings from interneurons were made using pipettes filled with an intracellular solution containing the following (in $\mathrm{mM}$ ): 90 potassium gluconate, $43.5 \mathrm{KCl}, 1.8 \mathrm{NaCl}, 1.7 \mathrm{MgCl}_{2}, 0.05$ EGTA, 10 HEPES, 2 Mg-ATP, $0.4 \mathrm{Na}_{2}$-GTP, 10 phosphocreatine, and 8 biocytin, pH 7.2 (270-290 mOsm; pipette resistance, 3-4.5 M 2 ). Recordings from pyramidal neurons were made using pipettes filled with the following intracellular solution (in mM): $40 \mathrm{CsCl}$, $90 \mathrm{~K}$-gluconate, $1.8 \mathrm{NaCl}, 1.7$ $\mathrm{MgCl}_{2}$, $3.5 \mathrm{KCl}$, 0.05 EGTA, 10 HEPES, 2 MgATP, $0.4 \mathrm{Na}_{2} \mathrm{GTP}, 10$ phosphocreatine, and 8 biocytin, pH 7.2 (270-290 mOsm). For paired recordings between Ivy cells and postsynaptic pyramidal cells, cells were patched in a modified ACSF solution (in $\mathrm{mm}$ ): $3.5 \mathrm{KCl}, 10$ glucose, $130 \mathrm{NaCl}, 1$ $\mathrm{NaH}_{2} \mathrm{PO}_{4}, 24 \mathrm{NaHCO} 3,4.3 \mathrm{MgSo} 4$, and $0.15 \mathrm{CaCl}$. In these instances, immediately after whole-cell configuration was achieved, recording ACSF (above) was allowed to wash on for 5-10 min before recordings began.

The following drugs were bath applied as noted in Results: DAMGO ([D-Ala $\left.{ }^{2}, \mathrm{NMe}-\mathrm{Phe}^{4}, \mathrm{Gly}_{-}{ }^{5}\right]$-enkephalin; Tocris Bioscience; catalog \#1171), CTAP (D-Phe-Cys-Tyr-D-Trp-Arg-Thr-Pen-Thr-NH $\mathrm{NH}_{2}$; Tocris Bioscience; catalog \#1560), tetrodotoxin (TTX; Tocris Bioscience; cata$\log \# 1078)$, and Deltrophin II ([D-Ala $\left.{ }^{2}\right]$-Deltorphin II; Tocris Bioscience; catalog \#1180).

After establishing whole-cell configuration, the firing pattern of recorded cells was examined by applying hyperpolarizing and depolarizing current steps of increasing amplitude (20 pA increase in step size per sweep, $1 \mathrm{~s}$ duration, one sweep every $3 \mathrm{~s}$ ). This cell-typing step was omitted in paired recordings; the cell-type identity of GFP or Tomato-positive cells from paired recordings was based on morphology. Adaptation ratio and continuous firing frequency were calculated for the first depolarizing step, producing a full sweep of action potentials. Adaptation ratio was defined as the average of the last three interspike intervals (ISIs) of the sweep, divided by the first ISI.

Similar to Sheffield et al. (2011), two protocols were used to study persistent firing. First, cells were selected that showed persistent firing during a protocol of increasing step sizes ( $20 \mathrm{pA}$ increase in step size per sweep, $1 \mathrm{~s}$ step duration, $3 \mathrm{~s}$ intersweep interval). Then, a second protocol was used, which consisted of current steps of a constant size (1 s step duration, $4 \mathrm{~s}$ intersweep interval). The size of this current step was adjusted to each individual cell and was based on the step size for which persistent firing was induced during the initial protocol. When persistent firing was induced multiple times (e.g., when studying the effect of DAMGO on persistent firing), we waited $3 \mathrm{~min}$ before reapplying this stimulation protocol (Sheffield et al., 2011). During this wait time, the cell was voltage clamped at $-60 \mathrm{mV}$.

When examining the effect of drugs on the baseline holding current (recordings in voltage-clamp mode), cells were voltage clamped at -60
$\mathrm{mV}$. Before examining the effect of drugs on membrane potential (recordings in current-clamp mode), cells were brought to a baseline membrane potential of $-60 \mathrm{mV}$ by injection of steady-state current. For paired recordings, the membrane potential of the presynaptic cell was continuously adjusted to maintain a membrane potential near $-65 \mathrm{mV}$, and action potentials were generated by injecting an additional 2-mslong, $1000-1500 \mathrm{pA}$ of current once every 5 s. Preliminary studies showed a stable postsynaptic response at this stimulation frequency. The postsynaptic cell was voltage clamped at $-60 \mathrm{mV}$, and series resistance was monitored by small $(5 \mathrm{mV})$ hyperpolarizing current steps; recordings were discarded if the series resistance changed $>25 \%$. Amplitudes of postsynaptic responses given are the average of consecutive sweeps, referred to as euIPSCs [effective unitary IPSCs, i.e., events including both successes and failures (Neu et al., 2007)].

Transgenic mouse strains. To target NPY-expressing interneurons for patch-clamp recordings, we used a commercially available mouse line expressing humanized Renilla GFP (hrGFP) under the NPY promoter B6.FVB-Tg(Npy-hrGFP)1Lowl/J [The Jackson Laboratory stock \#006417 (van den Pol et al., 2009)]. Mice were phenotyped at birth using GFsP-5 (miner's lamp goggles) from Biological Laboratory Equipment, Maintenance, and Service. These mice are referred to as "NPY-GFP" in this manuscript.

To target PV-expressing interneurons for patch-clamp recordings, we crossed a commercially available PV-Cre line [B6;129P2Pvalbtm1(cre)Arbr/J; The Jackson Laboratory stock\#008069 (Hippenmeyer et al., 2005)] with a commercially available red reporter line [B6;129S6Gt(ROSA)26Sortm9(CAG-tdTomato)Hze/J; The Jackson Laboratory stock \#007905 (Madisen et al., 2010)], to produce mice expressing the red fluorescent protein tdTomato in PV-expressing cells. These offspring are referred to as "PV-TOM" in this manuscript.

As described in the text, for a subset of experiments, these PV-TOM mice were then crossed with NPY-GFP mice, producing mice in which GFP was expressed in NPY-expressing neurons and in which tdTomato labeled PV-positive neurons.

When noted, to test the specificity of DAMGO action, homozygote

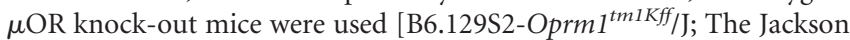
Laboratory stock \#007559 (Matthes et al., 1996)].

Anatomical methods. After the recordings, slices were fixed in $0.1 \mathrm{~m}$ phosphate buffer containing $4 \%$ paraformaldehyde and $0.1 \%$ picric acid for $2 \mathrm{~d}$ at $4^{\circ} \mathrm{C}$. For immunocytochemistry, after fixation, slices were resectioned at $60 \mu \mathrm{m}$. Sections were then incubated with one (mouse or rabbit) or two (one mouse, one rabbit) of the following primary antibodies raised against neuronal nitric oxide synthase (nNOS) (1:1000 rabbit anti-nNOS), PV (Swant PV28, 1:1000, polyclonal rabbit or Sigma P3088, 1:2000, monoclonal mouse), or reelin (Millipore MAB536, monoclonal mouse, $1: 1000$ ) overnight in $0.5 \%$ Triton $\mathrm{X}-100$ and $2 \%$ normal goat serum containing TBS buffer at $4^{\circ} \mathrm{C}$. Immunoreactions were revealed using appropriate Alexa Fluor 488-, Alexa Fluor 594-, or Dylight-649conjugated secondary goat antibodies against rabbit or mouse IgGs, and biocytin staining was revealed using Alexa Fluor 350-conjugated streptavidin. After determining the immunoreactivity of the recorded cells, some sections were further processed to reveal the fine details of the morphology of the cells using the conventional diaminobenzidine (DAB) staining method. Briefly, after washing in phosphate buffer, endogenous peroxidase activity was blocked with $1 \% \mathrm{H}_{2} \mathrm{O}_{2}$. After another wash, sections were incubated with $\mathrm{ABC}$ reagent (Vectastain $\mathrm{ABC}$ Elite kit, 1:500; Vector Laboratories) in 0.1\% Triton X-100-containing buffer for $1 \mathrm{~h}$ at room temperature. Sections were preincubated with $\mathrm{DAB}$ and $\mathrm{NiCl}_{2}$, and the reactions were developed with $0.2 \% \mathrm{H}_{2} \mathrm{O}_{2}$ for 3-10 min. Sections were dehydrated (50, 70, 90, and 95\%; absolute ethanol and CitriSolv solutions) on slides and mounted using DPX mounting medium (Electron Microscopy Sciences). For recordings with presynaptic PV basket cells, resectioning was omitted, slices were incubated for 2-3 h in $\mathrm{ABC}$ reagent and preincubated with $\mathrm{DAB}$ and $\mathrm{NiCl}_{2}$ for $15 \mathrm{~min}$, and an additional $100 \%$ ethanol dehydration step was included. Cells were visualized with epifluorescence or conventional transmitted light microscopy (Axioskop 2; Carl Zeiss). The axonal arbors and the dendrites of cells were drawn with camera lucida using a $100 \times$ objective. 
Statistical analysis. Data and statistical analysis was done using Clampfit 9, OriginPro 8, and Microsoft Excel 2007. Unless otherwise noted, paired or unpaired (as appropriate) two-tailed Student's $t$ tests were used. In cases in which data did not show a normal distribution (i.e., failed the Shapiro-Wilk test), Wilcoxon's signed rank or Mann-Whitney tests for paired and unpaired data, respectively, were used. ANOVAs were followed by Tukey's tests for mean comparisons. Data are presented as mean \pm SEM.

\section{Results}

Ivy and NGF cells express NPY (Price et al., 2005; Fuentealba et al., 2008). To target these cells for whole-cell patch-clamp recordings, we used NPY-GFP mice [described in Materials and Methods (van den Pol et al., 2009)]. Ivy and NGF cells could be distinguished from other NPY-expressing cells by (1) general morphology visible under both DIC and fluorescence, (2) firing pattern, (3) immunocytochemistry, and (4) axon location and morphology. Specifically, Ivy and NGF cells had small, round or oval somata (typically $10-20 \mu \mathrm{m}$ in diameter under DIC) and a multipolar morphology (viewed under fluorescence). These cells typically displayed a late-spiking (LS) firing pattern, with (1) little to no "sag" in response to hyperpolarizing current steps, (2) a slow depolarizing ramp near threshold, with delayed action potentials (i.e., late spiking), and (3) regular spiking action potentials at suprathreshold current injections [adaptation ratio, $1.28 \pm 0.08$; continuous firing frequency in response to a depolarizing current step, $20.7 \pm 1.5 \mathrm{~Hz}$ (Ascoli et al., 2008)]. Ivy and NGF cells often express nNOS but not cholecystokinin (CCK) or PV (Price et al., 2005; Fuentealba et al., 2008; Tricoire et al., 2010). Finally, Ivy and NGF cells have thin axons that form a dense, local plexus (Fig. 1A,B). Except when noted, all Ivy and NGF cells included in this study were filled with biocytin and recovered for post hoc analysis.

\section{NPY-expressing Ivy and neurogliaform cells are modulated by $\boldsymbol{\mu}$-opioid receptors}

Using hippocampal slices from NPY-GFP mice, we recorded from GFP-expressing Ivy and NGF cells throughout CA1. Bath application of the $\mu \mathrm{OR}$ agonist DAMGO $(1 \mu \mathrm{M})$ produced robust outward currents in these cells (all layers combined, $26.5 \pm 2.2$ $\mathrm{pA}, p<0.05 \times 10^{-9}, n=23$ cells). In contrast to NGFs, Ivy cells are located in or near the SP and rarely express the cellular marker reelin (Fuentealba et al., 2008, 2010). We therefore compared the DAMGO-induced shifts in reelin-positive NPY-LS cells (neurogliaform) and reelin-negative NPY-LS cells (Ivy cells). There was no difference between these cell groups, indicating that both are equally inhibited by $\mu \mathrm{OR}$ (reelin negative, $25.7 \pm 4.2 \mathrm{pA}, n=12$; reelin positive, $25.5 \pm 5.4 \mathrm{pA}, n=5 ; p=0.98$; Fig. $1 C$ ). NPY-LS cells may also be subdivided by nNOS immunoreactivity and developmental origin (Tricoire et al., 2010). We therefore also compared nNOS-positive NPY-LS and nNOS-negative NPY-LS cells. There was also no difference between these groups (nNOS positive, $20.6 \pm 1.3 \mathrm{pA}, n=7$; nNOS negative, $28.3 \pm 3.7 \mathrm{pA}, n=$ $11 ; p=0.07)$. We further compared DAMGO responsiveness between NPY-LS cells based on the location of their soma. There was no difference in DAMGO responsiveness between CA1 layers [stratum oriens (SO), $32.1 \pm 2.3 \mathrm{pA}, n=4$; SP, $19 \pm 2.3 \mathrm{pA}, n=6$; stratum radiatum, $30.8 \pm 5.5 \mathrm{pA}, n=7$; $\mathrm{SLM}, 25.1 \pm 3.6 \mathrm{pA}, n=6$; $p=0.15$, ANOVA]. In a separate set of experiments, DAMGO induced shifts in the presence of $1 \mu \mathrm{M}$ TTX $(26.8 \pm 6.9 \mathrm{pA}, n=7$ cells, $p<0.01$; Fig. $1 C$ ), suggesting a direct effect of DAMGO on $\mu$ ORs.

These recordings were all done in juvenile mice. To examine whether these findings of $\mu \mathrm{OR}$ modulation of NPY-LS cells ex- tended to adults, we additionally recorded from an adult male NPY-GFP mouse (postnatal day 214). NPY-LS cells, across all layers, still showed strong DAMGO-induced shifts in holding current ( $31.7 \pm 3.4 \mathrm{pA}, n=5$ cells, $p<0.05$; Fig. $1 C)$.

Although DAMGO is a selective $\mu \mathrm{OR}$ agonist (Handa et al., 1981; Raynor et al., 1994), we confirmed the specificity of DAMGO application on $\mu$ ORs by applying the $\mu$ OR-selective antagonist CTAP (Pelton et al., 1986). Because the DAMGOinduced shift desensitized (Fig. 1D), for these control experiments, we preapplied CTAP. When $500 \mathrm{~nm}$ CTAP was preapplied, DAMGO failed to induce a shift in holding current $(2.2 \pm 1.4 \mathrm{pA}, n=7$ cells, $p=0.17$; Fig. $1 C)$. CTAP alone had no effect on baseline holding currents $(-0.57 \pm 3.2 \mathrm{pA}, n=7$ cells, $p=0.86$; Fig. $1 C$ ), indicating little or no tonic inhibition by $\mu \mathrm{OR}$ of NPY-LS cells under these recording conditions.

To further confirm that the observed effect of DAMGO was mediated by $\mu$ ORs, we recorded from Ivy and NGF cells in slices taken from $\mu$ OR knock-out mice (Matthes et al., 1996). DAMGO had no effect on holding current for these cells $(0.1 \pm 2.3 \mathrm{pA}, n=$ 5 cells, $p=0.97$; Fig. $1 C$ ).

A subpopulation of NPY-expressing cells expresses the $\delta$-opioid receptor ( $\delta \mathrm{OR})$ (Williams et al., 2011). To test the possibility that these include the neurogliaform family of cells in CA1, we tested the $\delta$ OR agonist Deltorphin II on NGF and Ivy cells. Deltorphin II $(1 \mu \mathrm{M})$ produced no baseline shift in these cells $(1.3 \pm 3.1 \mathrm{pA}, n=6$ cells, $p=0.69)$, indicating that these cells do not express $\delta$ ORs.

\section{Ivy and NGF cells are affected by similar concentrations of DAMGO as PV basket cells, but DAMGO produces a smaller hyperpolarization in Ivy and NGF cells}

It has been reported previously that FS, PV-expressing, basket cells in CA1 are strongly modulated by the $\mu$-opioid agonist DAMGO, whereas only occasional regular spiking (RS), CCKexpressing basket cells are DAMGO sensitive (Neu et al., 2007; Glickfeld et al., 2008). To target PV-expressing basket cells, we used an additional strain of mice, expressing a red fluorescent marker, tdTomato, in PV expressing cells (PV-TOM; details in Materials and Methods). Because other, non-basket cell types can also express PV (Freund and Buzsáki, 1996), PV-TOM recorded cells were recovered for post hoc analysis of morphology, and only those showing a perisomatic-targeting, basket morphology were included in this study. DAMGO $(1 \mu \mathrm{M})$ produced hyperpolarizing shifts in the membrane potential in both Ivy/NGF cells and PV basket cells (Ivy/NGF, $6.6 \pm 0.8 \mathrm{mV}, n=21$ cells, $p<0.01 \times$ $10^{-5}$; PV basket, $11.3 \pm 1.2 \mathrm{mV}, n=6$ cells, $\left.p<0.001\right)$. On average, shifts were larger in PV basket cells, but there was a large degree of overlap (Ivy/NGF range, 2-15 mV; PV basket range, $7-15 \mathrm{mV}$; Ivy/NGF vs PV basket, $p<0.01$; Fig. $2 A-C)$. To ensure that the background strains were not a confounding factor, we crossed the NPY-GFP and PV-TOM lines and performed additional recordings from Ivy/NGF and PV basket cells from animals resulting from this cross. There was no difference between Ivy/ NGF cells collected from these two lines, nor was there any difference between strains for PV basket cells (Ivy/NGF, NPY-GFP vs cross, $p=0.73$, Mann-Whitney test; PV basket, PV-TOM vs cross, $p=0.55$; Fig. $2 C$ ).

The effect of DAMGO on both cell populations (Ivy/NGF and PV basket) was also compared for recordings made in voltage-clamp mode. In this case, the difference between Ivy/NGF and PV basket cells was more obvious, with no overlap between populations (Ivy/ NGF range, $10-52 \mathrm{pA}, n=23$; PV basket range, $124-207 \mathrm{pA}, n=5$; Fig. $2 D, E$ ). The larger differences seen between DAMGO shifts in 
A

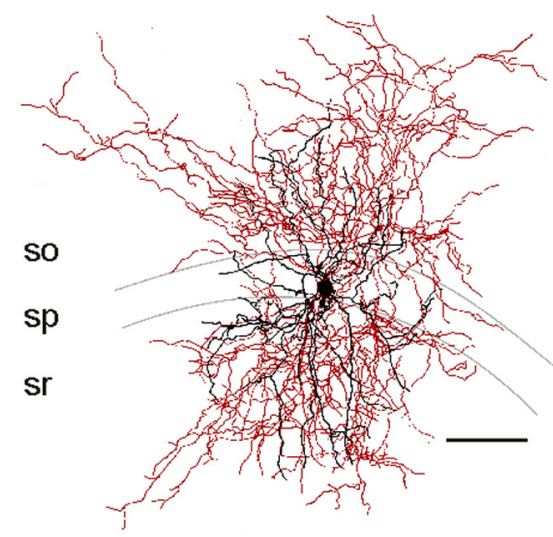

B

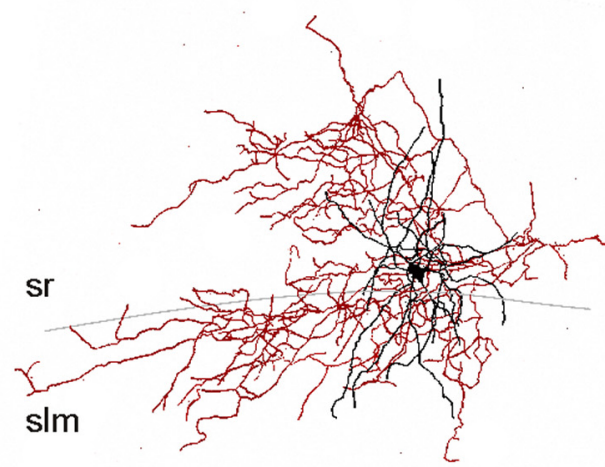

C

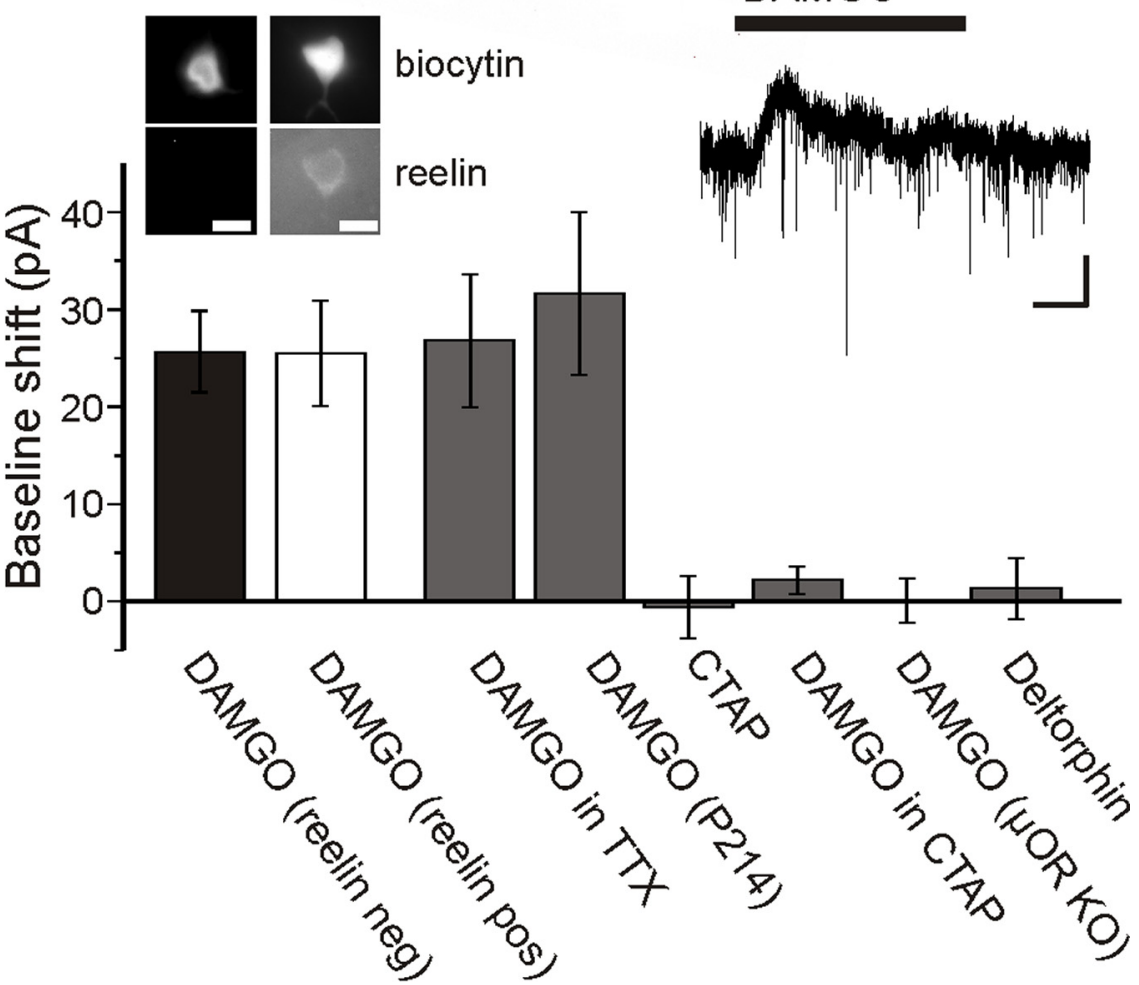

Figure 1. Ivy and neurogliaform cells are modulated by $\mu 0 \mathrm{Rs}$. Ivy and neurogliaform cells were targeted for recordings using an NPY-GFP mouse line. $\boldsymbol{A}$, A reconstructed lvy cell (left) whose soma was located in the stratum pyramidale (sp). This cell expressed GFP (green) but did not show immunoreactivity for PV (red) (right, top). Right, Bottom, Response to hyperpolarizing and depolarizing current steps. $\boldsymbol{B}$, A reconstructed NGF cell, located at the border between stratum radiatum (sr) and stratum lacunosum-moleculare (sIm). C, Comparison of currents induced by DAMGO (an $\mu$ OR-selective agonist) in reelin immuno-negative (black bar; example cell, top left) and reelin immuno-positive (white bar; example cell, top right) neurogliaform family cells and shifts seen in neurogliaform family cells in response to application of DAMG0 in the presence of TTX, DAMGO for slices from an adult
Ivy/NGF and PV basket cells in voltageclamp over current-clamp recordings is likely to be in part attributable to differences in input resistance between the two populations, which also had non-overlapping distributions (Ivy/NGF range, 155-395 M $\Omega$; PV basket range, $51-120 \mathrm{M} \Omega$; Ivy/NGF vs PV basket, $p<0.01 \times 10^{-5}$; Fig. $2 E$ ).

We additionally recorded from PV basket cells and Ivy/NGF cells in rat. As in mouse, these cells showed significant shifts in baseline holding current in the presence of $1 \mu \mathrm{M}$ DAMGO (Ivy/NGF, $53.7 \pm 7.1 \mathrm{pA}$, $n=12$ cells, $p<0.01 \times 10^{-2}$; PV basket, $197.0 \pm 30.0$ pA, $n=4$ cells, $p<0.01$; Fig. $2 D)$. Also, as in mouse, rat PV basket cells showed significantly greater shifts compared with rat Ivy/NGF cells and significantly smaller input resistances (Ivy/NGF vs PV basket baseline shifts, $p<0.01 \times 10^{-3}$; Ivy/NGF vs PV basket $R_{\text {in }}, p<0.01 \times 10^{-4}$; Fig. $2 D, E$ ). Again, as in mouse, these were non-overlapping distributions. We also found that, for both cell types, DAMGO induced greater shifts in rat than in mouse. A two-way ANOVA, with species as a factor 1 and cell type as factor 2 , revealed an effect of both species (mouse vs rat) and cell type (Ivy/NGF vs PV basket), but no statistical interaction between factor 1 and factor 2, indicating that a similar difference in baseline shift between cell types is maintained across species (both cell types "scale-up" similarly in rat; Fig. 2D).

Finally, to compare sensitivity to ligand, we constructed dose-response (concentration-response) curves for both Ivy/NGF and PV basket cells. To avoid complications attributable to desensitization, each cell was tested at only one dose. Responses were normalized to the average $1 \mu \mathrm{M}$ effect per cell type. There was no difference between Ivy/ NGF and PV basket dose-response curves $(p=0.84, F$ test; Fig. $2 F)$. Therefore, although there is cell-to-cell variability, at the population level, DAMGO has a similar potency relative to each $E_{\max }$ (Ivy/ NGF EC ${ }_{50}, 0.04 \mu \mathrm{M} ;$ PV basket $\mathrm{EC}_{50}, 0.06$ $\mu \mathrm{M})$ but a different efficacy (Ivy/NGF $E_{\max }, 26.5 \pm 2.2 \mathrm{pA}$; PV basket $E_{\max }$, $158.3 \pm 14.7$ pA; Fig. $2 D$ ).

$\leftarrow$

animal (postnatal day 214), CTAP (an $\mu 0 \mathrm{R}$-selective antagonist), DAMGO in the presence of (TAP, DAMGO for slices taken from $\mu O R$ knock-out mice, and the $\delta 0 R$ agonist Deltorphin II (gray bars). $\boldsymbol{D}$, An example (same cell as in $\boldsymbol{A}$ ) of the desensitizing outward current produced by the application of the DAMGO (1 $\mu \mathrm{m}$, black bar). For clarity, artifacts have been removed. Scale bars: $\boldsymbol{A}, \boldsymbol{B}$, left, $50 \mu \mathrm{m} ; \boldsymbol{A}, \boldsymbol{B}$, right top, $10 \mu \mathrm{m} ; \boldsymbol{C}$, $10 \mu \mathrm{m}$. Calibration: $\boldsymbol{A}, \boldsymbol{B}$, bottom right, $20 \mathrm{mV}$ or $80 \mathrm{pA}, 200$ $\mathrm{ms} ; \boldsymbol{D}, 200 \mathrm{pA}, 100 \mathrm{~s}$. 
A
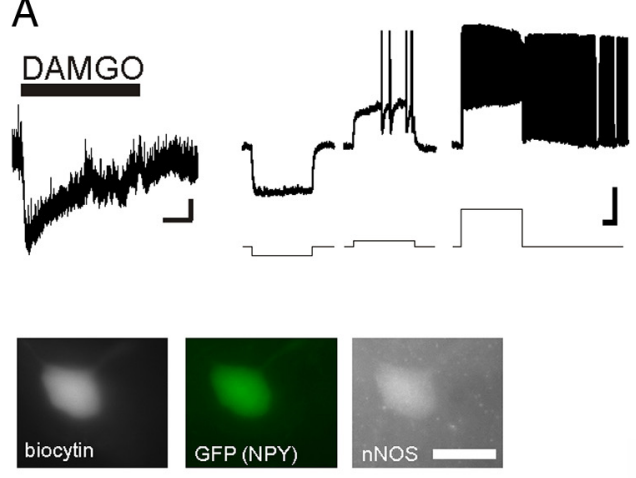

C

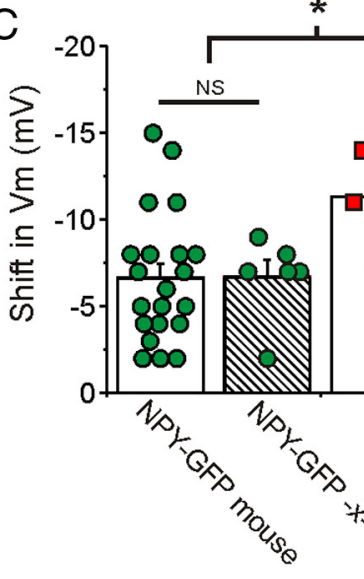

$\mathrm{D}$

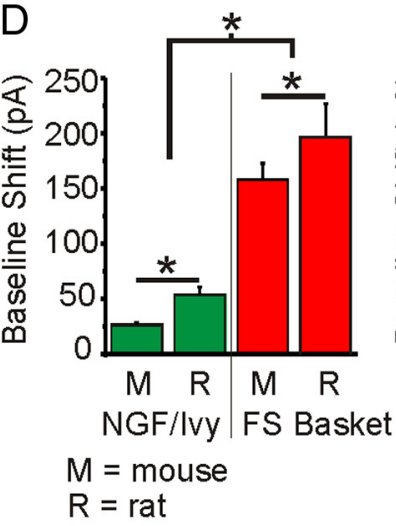

$\mathrm{E}$
B
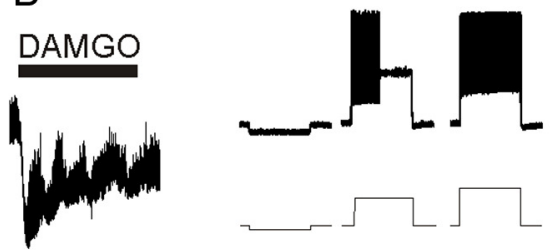

O LS NGF/Ivy Cells $\square$ FS Basket Cells
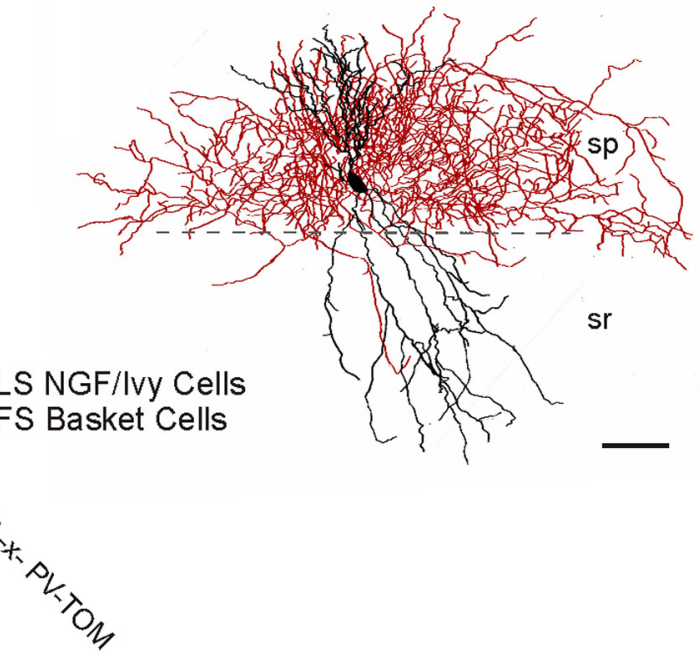

$\mathrm{F}$
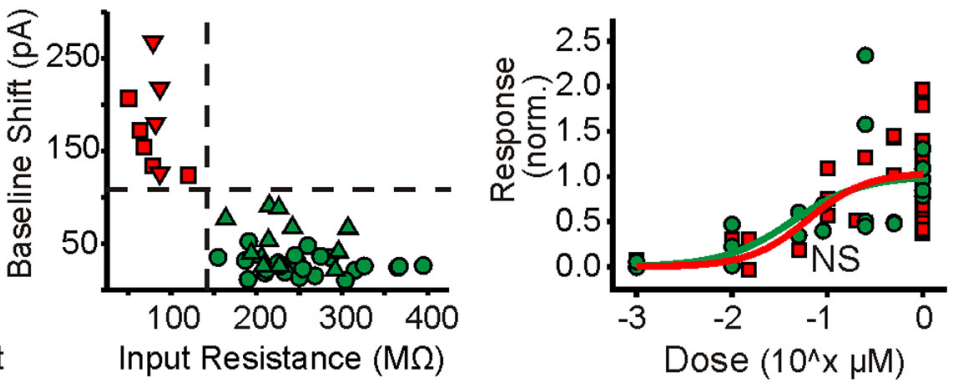

oLS NGF/lvy-mouse aFS Basket - mouse

$\triangle$ LS NGF/lvy - rat

$\nabla F S$ Basket - rat

Figure 2. Neurogliaform family interneurons and PV basket cells have similar DAMGO sensitivity. A, In current clamp, application of $1 \mu \mathrm{m}$ DAMGO (black bar) hyperpolarizes (left trace) the cell. This cell expressed GFP (under the NPY promoter) and showed immunoreactivity for nNOS (bottom) and displayed an LS firing pattern (right traces). Note that, at higher current injections, after the cell had fired many action potentials, persistent firing was induced (see also Fig. 4 and related text). This cell was recorded from the NPY-GFP mouse line. B, Application of $1 \mu \mathrm{m}$ DAMGO produces a similar, desensitizing, hyperpolarization in an FS basket cell expressing tdTomato (TOM). This cell was recorded from the PV-TOM mouse line. Note that the apparent rhythmicity in the response seen for this cell in the presence of DAMG0 was observed in 3 of 11 PV-TOM basket cells. For clarity, in $\boldsymbol{A}$ and $\boldsymbol{B}$, artifacts have been removed. Bottom, Reconstruction of this FS PV-expressing basket cell. C, DAMG0-induced hyperpolarization by cell type (PV basket cells, squares; NGF/lvy, circles) and mouse line (hashed bars, NPY-GFP crossed with PV-TOM). Note that the distributions of PV and NPY cell responses showed substantial overlap (red squares vs green circles, each symbol represents the response of an individual cell). For each cell type, there was no difference in baseline shift between mouse strains (NS). PV basket cells showed significantly larger shifts in membrane potential than NGF/lvy cells (asterisk). D, Voltage-clamp recordings of DAMG0-induced shifts in holding current in rat (R) and in mouse (M) for both NGF/lvy (green, left 2 bars) and PV basket (red, right 2 bars) cells. $E$, In rat (triangles) and in mouse (circles and squares), PV basket cells (red symbols) had smaller input resistances and greater DAMG0-induced shifts in holding current than NGF/lvy cells (green symbols). These distributions were non-overlapping (dotted lines). $\boldsymbol{F}$, In mouse, responsiveness to a range of DAMGO concentrations was tested in voltage clamp on PV basket cells and NGF/lvy cells and normalized to the average response per cell type to $1 \mu \mathrm{mDAMGO}$. The resulting dose-response curves (solid lines) were not significantly different. Each symbol represents the response of an individual cell (each cell was tested at only one concentration). Green circles, LS NGF/lvy cells; red squares, FS basket cells. Error bars indicate SEM; ${ }^{*} p<0.05$; NS, not significant. sp, stratum pyramidale; sr, stratum radiatum; Calibration: $\boldsymbol{A}, \boldsymbol{B}$ : shifts in membrane potential: $2 \mathrm{mV}, 200 \mathrm{~s} ; \boldsymbol{A}, \boldsymbol{B}$, response to current steps: $200 \mathrm{~ms}, 2 \mathrm{mV}$ or $400 \mathrm{pA}(\boldsymbol{A})$ or $800 \mathrm{pA}(\boldsymbol{B})$. Scale bar: $\boldsymbol{B}$, basket cell reconstruction, $50 \mu \mathrm{m}$.

GABA release from Ivy cells is strongly inhibited by $\mu$-opioid receptor activation

Results above indicate that Ivy cells are inhibited by $\mu$ ORs through somatic hyperpolarization. To test whether $\mu$ ORs are also functionally expressed at Ivy cell terminals, in which they would more directly inhibit neurotransmitter release, we performed paired recordings between synaptically coupled Ivy cells and nearby pyramidal cells. Application of $1 \mu \mathrm{M}$ DAMGO greatly reduced euIPSCs, which was reversed by application of $500 \mathrm{nM}$ CTAP (predrug, $10.9 \pm 2.0 \mathrm{pA}$; DAMGO, $0.99 \pm 0.6 \mathrm{pA}$; 
+CTAP, $9.5 \pm 1.8 \mathrm{pA} ; n=7$ pairs; predrug vs DAMGO, $p<0.01$; Fig. $3 A$ ). In a subset of experiments, CTAP was not added for several minutes. In three of four pairs, there was no apparent desensitization of the DAMGO effect on euIPSC amplitude (Fig. 3B), in contrast to the desensitization seen for DAMGO effects on holding potential (Fig. $2 \mathrm{~A}$ ).

To further confirm the specificity of action of DAMGO on $\mu$ ORs, we performed additional recordings from synaptically coupled pairs in which the $\mu \mathrm{OR}$-selective antagonist was bath applied before the application of $1 \mu \mathrm{M}$ DAMGO. Preapplication of CTAP (500 nM) prevented the DAMGO effect on euIPSC amplitude (predrug, 8.6 \pm 3.0 pA; CTAP, $8.9 \pm 3.1$ pA; +DAMGO, $9.7 \pm 2.9 \mathrm{pA} ; n=3$ pairs; CTAP vs + DAMGO, $p=0.44$; Fig. $3 C$ ). CTAP alone had no apparent effect on euIPSC amplitude $(p=0.67)$, suggesting little to no tonic $\mu$ OR-mediated inhibition of neurotransmitter release from Ivy cells, mirroring results seen with shifts in holding current (above).

We additionally performed paired recordings between presynaptic PV basket cells and postsynaptic pyramidal cells and tested the effect of DAMGO on these. As with Ivy cell pairs, the euIPSC amplitude was strongly reduced by application of 1 $\mu \mathrm{M}$ DAMGO (predrug, $71.6 \pm 27.0 \mathrm{pA}$; DAMGO, $16.0 \pm 6.4 \mathrm{pA} ; n=7$ pairs, $p<$ 0.05 , Wilcoxon's signed ranks test; Fig. $3 D)$. For baseline shifts in holding current, similar $\mathrm{EC}_{50}$ values were found for PV basket and Ivy/NGFs (see above; Fig. $2 F)$. We therefore also tested a lower concentration $(0.05 \mu \mathrm{M})$ of DAMGO, a value near the calculated $\mathrm{EC}_{50}$ values for baseline shifts. For both PV basket and Ivy/NGFs, $0.05 \mu \mathrm{M}$ DAMGO produced approximately half the inhibition of euIPCS amplitude seen at $1 \mu \mathrm{M}$ DAMGO (Ivy cells, $1 \mu \mathrm{M}$ DAMGO, $94.3 \pm 9.3 \%$ reduction, $n=7$ pairs; Ivy cells, $0.05 \mu \mathrm{M}$ DAMGO, $49.0 \pm 9.7 \%$ reduction, $n=4$ pairs; note that half of the $1 \mu \mathrm{M}$ effect would be $47.1 \%$; PV basket cells $1 \mu \mathrm{M}, 76.9 \pm$ $10.5 \%, n=7$ pairs; PV basket cells $0.05 \mu \mathrm{M}, 33.5 \pm 14.3 \%, n=4$ pairs; note that half of the $1 \mu \mathrm{M}$ effect would be $38.5 \%$; Fig. $3 D$ ). Inhibition of euIPSC amplitude was not significantly different between cell types for either concentration (Ivy vs PV basket, 1 $\mu \mathrm{M}, p=0.80$, Mann-Whitney test; $0.05 \mu \mathrm{M}, p=0.41$ ). Together, these findings further support similar sensitivity to DAMGO for Ivy and PV basket cells.

\section{Ivy cells display persistent firing, and this persistent firing is delayed by DAMGO}

Certain interneurons can display persistent firing: after hundreds of action potentials, these cells will continue to fire in the absence of depolarizing current (Sheffield et al., 2011). The action potentials during persistent firing may originate in the axons themselves and backpropagate to the soma. This has been shown to occur with a high frequency for a population of cells in the SLM of CA1 and in the cortex; $\sim 80 \%$ of cells expressing the serotonin $5 \mathrm{~b}$ receptor in SLM of CA1 display persistent firing (Sheffield et al., 2011). During our recordings of NPY cells, we noted that these cells were also capable of exhibiting persistent firing. We further examined this in late-spiking NPY cells in and near SP (Ivy cells) by applying a protocol of depolarizing currents steps of increasing size and also by using repeated current steps of the same size. Both protocols were effective in evoking persistent firing (Fig. $4 A, B)$. We found that $82 \%$ of Ivy cells display persistent firing. In contrast, persistent firing was observed in $<20 \%$ of PV basket cells (Fig. 4C). Ivy cells required $885 \pm 55$ action potentials before displaying persistent firing, similar to reported values for SLM CA1 neurons (792 \pm 32 ; Sheffield et al., 2011). Firing persisted for $15.7 \pm 4.7 \mathrm{~s}$ (median, $17.2 \mathrm{~s}, n=9$ cells; Fig. $4 A$ ), a value intermediate to reported values for SLM CA1 cells and cortical interneurons (Sheffield et al., 2011). The maximum firing frequency $(80.3 \pm 9.6 \mathrm{~Hz})$ during persistent firing was higher than 

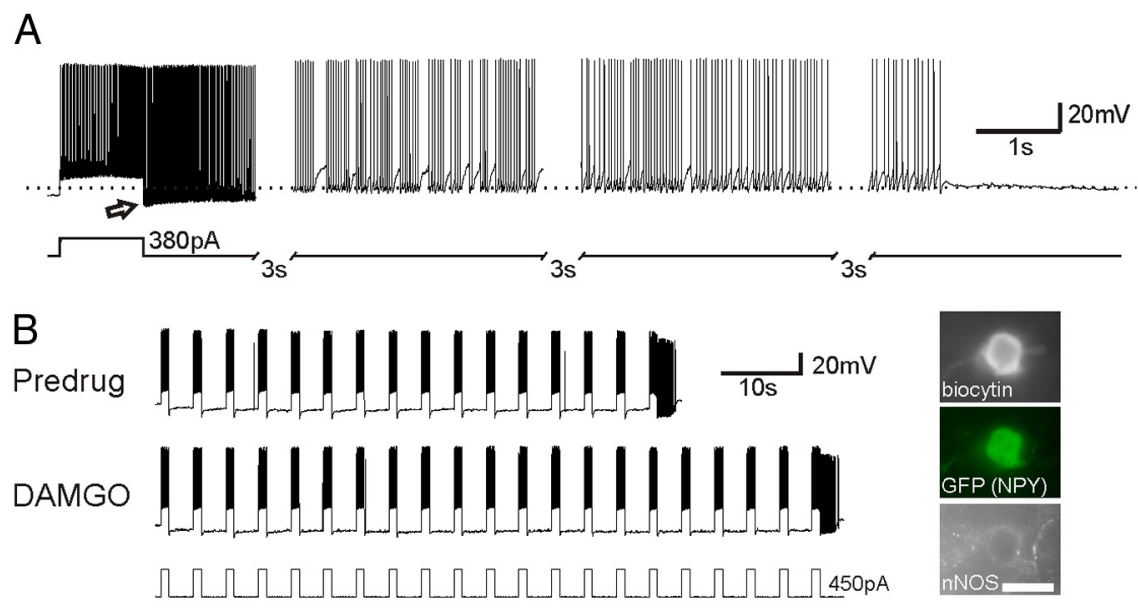

C

Predrug

DAMGO

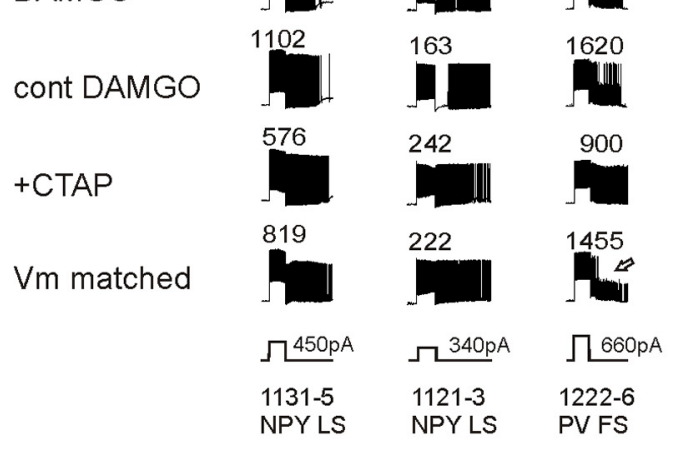

1131-5 NPY LS

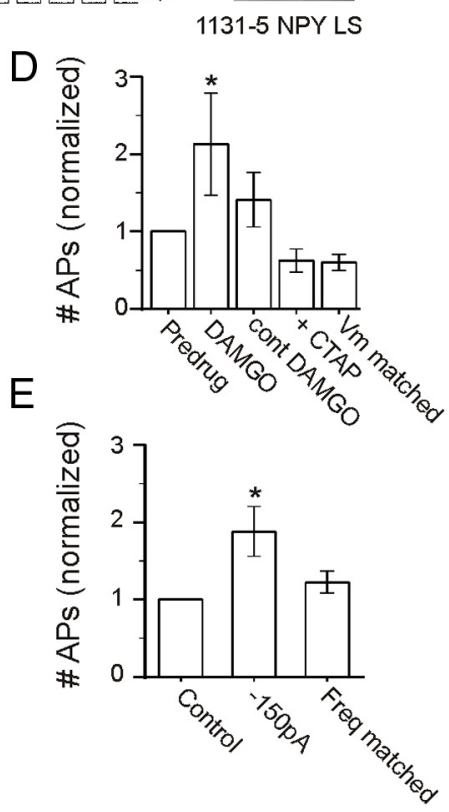

Figure 4. Ivy cells display persistent firing, and induction of persistent firing is inhibited by DAMGO. A, Median duration of persistent firing seen in lvy cells after increasing depolarizing current steps (only the last current step is shown). Note the apparent hyperpolarized action potential threshold at the start of persistent firing (arrow), typical of persistent firing. $\boldsymbol{B}$, After repeated current steps, another lvy cell displays persistent firing. In the presence of DAMGO $(1 \mu \mathrm{M})$, induction of persistent firing is delayed. Right, This cell expressed GFP and showed immunoreactivity for nNOS. C, Responses to final depolarizing steps before persistent firing for three example cells, including two Ivy cells (cell 1131-5 is shown also in $\boldsymbol{B}$ ) and one PV basket cell. Shown is before drug addition, in DAMGO, in the continued presence of DAMGO, with the addition of CTAP, and finally with somatic hyperpolarization to match that seen initially in DAMGO (labeled as "Vm matched"). Note that, in all cases, DAMG0 increased the number of action potentials required to induce persistent firing (small numbers above current-clamp traces). Note also that the number of spikelets (arrows) in the FS PV basket cell increased in DAMGO and with direct somatic hyperpolarization to match the membrane potential seen in DAMG0. D, Summary graph of the number of action potentials (APs) required to induce persistent firing per condition, normalized to that required before drug addition ( $n=6$ cells). $\boldsymbol{E}$, The effect of strong somatic hyperpolarization $(-150 \mathrm{pA})$ on the number of action potentials required to induce persistent firing ( $n=11$ cells). The depolarizing step was increased by $150 \mathrm{pA}$ to compensate, but a decrease in firing frequency was still observed. Therefore, after the strong hyperpolarization was removed, the step size was decreased to match the average firing frequency observed during strong hyperpolarization ("Freq matched"). On two occasions (once with DAMG0 application and once with strong hyperpolarization), the inhibition of persistent firing induction was so strong that persistent firing was not induced even after 100 depolarizing current steps; for analysis purposes, the number of action potentials fired during these 100 sweeps was used. ${ }^{*} p<0.05$, Wilcoxon's signed ranks test. Scale bar: $\boldsymbol{B}, 10 \mu \mathrm{m}$. Calibration: $\mathrm{C}, 20 \mathrm{mV}, 1 \mathrm{~s}$.

that reported for SLM cells (Sheffield et al., 2011) and was reached more quickly $(646 \pm 203 \mathrm{~ms})$. Spikelets [which reflect a failure of action potentials to propagate to the soma (Sheffield et al., 2011); Fig. 4C, arrows] and a low apparent threshold for action potentials during persistent firing (Fig. $4 \mathrm{~A}$, arrow) were also observed $(-68.1 \pm 3.8 \mathrm{mV}$ for the first spike of persistent firing, vs $-43.3 \pm 2.4 \mathrm{mV}$ for the first spike in response to a

depolarizing current step), again consistent with persistent firing reported for SLM cells (Sheffield et al., 2011). These recordings were all done in juvenile animals. Of interest, we found in an adult NPY-GFP mouse (postnatal day 214) that Ivy and NGF also displayed persistent firing ( $n=5$ of 5 recovered cells). Persistent firing is therefore not a phenomenon restricted to juvenile animals.

We next asked whether $\mu \mathrm{OR}$ activation would inhibit persistent firing by applying DAMGO to cells showing persistent firing in control ACSF. In the presence of $1 \mu \mathrm{M}$ DAMGO, these cells were still capable of displaying persistent firing ( $n=4$ of 5 Ivy cells, 1 of 1 PV basket cell). However, in all cases, DAMGO increased the number of action potentials required to induce persistent firing (predrug, $1123 \pm 266$ action potentials required; DAMGO, $2171 \pm 582$ action potentials required; $n=6$ cells; $p<0.05$, Wilcoxon's signed ranks; Fig. $4 C$, compare number of action potentials in DAMGO to predrug conditions, $D$ ). In the continued presence of DAMGO, the effect decreased, suggesting desensitization. Addition of CTAP fully blocked the effect of DAMGO (CTAP, $669 \pm 178$ action potentials required). DAMGO also induced a sufficiently large hyperpolarization of the FS basket cell as to increase the number of spikelets (Fig. 4C, arrows).

The above data demonstrate that $\mu \mathrm{OR}$ activation inhibits the induction of persistent firing in Ivy cells. To see whether hyperpolarization of the recorded cell alone could mimic the effects of DAMGO on persistent firing, we first injected current to bring the membrane potential down to that seen in the presence of DAMGO. This somatic hyperpolarization of the recorded neuron mimicked only the effect on the rate of spikelets in the PV basket cell (Fig. $4 C, \mathrm{Vm}$ matched) but failed to replicate the increase in the number of action potentials required to induce persistent firing $\left(V_{\mathrm{m}}\right.$ matched, $693 \pm 226$ action potentials required; Fig. $4 D$ ). However, this mimicked only the hyperpolarization seen at the soma, and $\mu$ ORs are not limited to the cell body; therefore, in separate experiments, we tested the effect of strong hyperpolarization [note that, in these experiments, all 11 cells were GFP (NPY) positive and in or near SP, and 4 of 11 cells were recovered for post hoc analysis and confirmed Ivy cells]. After determining the number of action potentials required for a given cell to display persistent firing, cells were hyperpolarized $(-150 \mathrm{pA}$, bringing the membrane potential to $-91.4 \pm 2.0$ $\mathrm{mV}$ ). The depolarizing step was increased by $150 \mathrm{pA}$ to compensate. With this extreme hyperpolarization, an increase in action potentials required to induce persistent firing was observed (con- 
trol, $1118 \pm 150$ action potentials; with $-150 \mathrm{pA}, 1709 \pm 169$ action potentials; $n=11$ cells; $p<0.01$, Wilcoxon's signed ranks test; Fig. $4 E$ ). Despite the compensatory increase in step size, the average firing frequency was decreased in the $-150 \mathrm{pA}$ condition (control, $66.1 \pm 2.1 \mathrm{~Hz}$; with -150 pA, $49.5 \pm 4.3 \mathrm{~Hz} ; p=0.01$ ). Therefore, with the cell returned to control membrane potentials, we then decreased the step size to match the average firing frequency seen when the cell was hyperpolarized (frequency matched, $47.7 \pm 4.0 \mathrm{~Hz}$ vs $49.5 \pm 4.3 \mathrm{~Hz}$ when the cell hyperpolarized). Despite the lower average firing frequency, there was no increase in the number of action potentials required to induce persistent firing (control, $1118 \pm 150$, see above; frequency matched, $1251 \pm 124$ action potentials required; control vs frequency matched, $p=0.46$, Wilcoxon's signed ranks test; Fig. $4 E$ ). Therefore, the increase in the number of action potentials required with strong $(-150 \mathrm{pA})$ hyperpolarization was unlikely to be attributable to the effect on firing frequency. This is in keeping with previous findings that, for a given protocol, it is the number of action potentials, rather than the firing frequency, that is important for the induction of persistent firing (Sheffield et al., 2011).

\section{Discussion}

Here we report that the neurogliaform family, a major class of dendritically targeting interneurons, is a previously unidentified target of $\mu \mathrm{OR}$ modulation in CA1 of the hippocampus. The $\mu$ OR-selective agonist DAMGO produces inhibitory currents in Ivy and NGF cells across all layers of CA1. This inhibition is seen at DAMGO concentrations similar to those producing inhibition in perisomatic-targeting PV FS basket cells, the interneuron type classically associated with $\mu \mathrm{OR}$ expression. Furthermore, using paired recordings between synaptically coupled Ivy and pyramidal cells, we find that $\mu \mathrm{OR}$ suppresses neurotransmitter release from Ivy cells, reducing the postsynaptic response to a mere $9 \%$ of control IPSCs. Unlike the DAMGO-induced hyperpolarization observed during single-cell somatic recordings, this inhibition of Ivy cell terminals does not show rapid desensitization. We further report that a high proportion of Ivy cells show the recently described phenomenon of persistent firing (Sheffield et al., 2011). Finally, we find that induction of this persistent firing is also inhibited by $\mu \mathrm{OR}$ activation.

\section{Ivy and NGF are modulated by MORs}

Despite decades of research of the hippocampal opioid system, basic information on which CA1 cell types are modulated by $\mu \mathrm{ORs}$ is incomplete. $\mu \mathrm{ORs}$ are selectively expressed on interneurons in CA1 (Drake and Milner, 1999), but the identity of these interneurons is only partially understood. Immunocytochemistry indicates that a significant portion of PV-expressing interneurons are also $\mu \mathrm{OR}$ positive, but this accounts for only $42 \%$ of $\mu$ OR-positive interneurons in CA1 (Drake and Milner, 2002). Electrophysiology suggested that the majority of $\mu \mathrm{OR}$-expressing interneurons in SO were perisomatically targeting (Svoboda et al., 1999), and PV basket cells, but generally not CCK basket cells, are inhibited by $\mu$ ORs (Neu et al., 2007; Glickfeld et al., 2008). However, as discussed in Introduction, another unidentified class of $\mu \mathrm{OR}$-expressing interneurons must also exist. Inhibition across all layers of CA1, rather than just SP, is inhibited by $\mu \mathrm{OR}$ activation (McQuiston, 2008). Furthermore, agatoxin blocks neurotransmission from PV basket cells (Hefft and Jonas, 2005), yet agatoxin-insensitive IPSPs remain DAMGO sensitive, and $\mathrm{GABA}_{\mathrm{B}}$-mediated IPSPs are even more sensitive to DAMGO than $\mathrm{GABA}_{\mathrm{A}}$-mediated IPSPs (Lafourcade and Alger, 2008).
How did Ivy and neurogliaform cells, which represent nearly $40 \%$ of interneurons in CA1 (Fuentealba et al., 2008), remain unrecognized as a target of $\mu \mathrm{OR}$ modulation for so long? One explanation is that, until relatively recently, there has been a general neglect of this prominent cell type. In fact, Ivy cells were only first reported in 2008 (Fuentealba et al., 2008). Another possible explanation is the initial difficulty in finding appropriate cellular markers for neurogliaform cells; NPY was identified as the most consistent neuromarker for NGFs in 2005 (Price et al., 2005). However, other interneuron populations also express NPY (Freund and Buzsáki, 1996; Klausberger, 2009; van den Pol et al., 2009). In CA1 SO alone, in addition to neurogliaform family cells, bistratified and a potentially heterogeneous population of GABAergic projecting neurons express NPY (Klausberger, 2009). A portion of NPY cells in CA1 were reported to express $\mu$ ORs, but their identity was unknown (Drake and Milner, 2002). Our findings that Ivy and NGF cells are modulated by $\mu$ ORs explain previous findings, discussed above, which indicated that PV basket cells account for only a portion of $\mu \mathrm{OR}$-expressing interneurons. Furthermore, because Ivy and NGF cells are dendritically targeting, unlike PV basket cells, our results broaden our general understanding of $\mu \mathrm{OR}$ modulation of interneurons.

\section{Functional implications of MOR modulation of Ivy and NGF cells}

The finding of $\mu \mathrm{OR}$ modulation of Ivy and NGF cells also provides greater clarity when examining additional effects of $\mu \mathrm{OR}$ activation in CA1. For example, activation of perforant path input can produce strong inhibition in CA1 pyramidal neurons (Soltesz and Jones, 1995), which is mediated by both $\mathrm{GABA}_{\mathrm{A}}$ and $\mathrm{GABA}_{\mathrm{B}}$ receptors (Empson and Heinemann, 1995; DvorakCarbone and Schuman, 1999). This feedforward inhibition is $\mu \mathrm{OR}$ modulated and regulates integration of temporo-ammonic pathway input and Schaffer collateral input (McQuiston, 2011). In light of the present findings, this disinhibition of the system by $\mu$ ORs can now be understood to be attributable in part to their action on the neurogliaform family of interneurons, which receives input from both pathways (Price et al., 2005). Activation of $\mu$ ORs, likely through its disinhibition of the network, facilitates plasticity, and $\mu \mathrm{OR}$ knock-out mice show reduced radial-maze and Morris water-maze performance (Jamot et al., 2003). Given the ability of NGFs to produce $\mathrm{GABA}_{\mathrm{B}}$ responses (Tamás et al., 2003; Price et al., 2005) and operate via volume transmission (Oláh et al., 2009), affecting output of terminals within their axonal plexus, expression of $\mu$ ORs by NGF and Ivy cells was a missing link in better understanding how $\mu \mathrm{OR}$ activation affects circuit function and plasticity.

Neurogliaform and Ivy cells are found in a range of anatomical structures, including cortex (Kisvárday et al., 1990), dentate gyrus (Armstrong et al., 2011), CA3 (Szabadics and Soltesz, 2009; Szabadics et al., 2010), amygdala (McDonald and Culberson, 1981), and habenular nucleus (Weiss and Veh, 2011). Modulation of the neurogliaform family by $\mu$ ORs across brain structures, should that be found in future studies, would have sweeping consequences, relevant to a wide spectrum of processes and behaviors, including learning and reward processing. This is especially noteworthy given the highly addictive nature of opiates.

Long-term potentiation of mossy fiber input to CA3 is inhibited by blocking opioid receptors and facilitated by DAMGO (Jin and Chavkin, 1999). Importantly, this action is dependent on $\mathrm{GABA}_{\mathrm{B}}$ receptors, and, therefore, in this area also, neurogliaform and ivy cells and their $\mu \mathrm{OR}$ receptors may be key players in modulating plasticity. It is also of interest that a high percentage of 
cortical NPY-expressing cells in layer 1 express $\mu$ ORs (Férézou et al., 2007). Future studies are needed to examine not only neurogliaform family cells in other areas but also which other NPYexpressing cell types are potentially modulated by $\mu$ ORs [note that additional data from our experiments (data not shown) suggest that some non-Ivy/NGF, NPY-expressing cell types in the CA1 may be modulated by DAMGO].

Sheffield et al. (2011) recently described the phenomenon of persistent firing in a subset of cells in SLM of CA1. These cells express the serotonin $5 \mathrm{~b}$ receptor and display persistent firing at a high frequency ( $\sim 80 \%$ of cells). Serotonin $5 \mathrm{~b}$ receptor-expressing cells in the cortex were also found to display persistent firing, albeit with slightly different properties and at lower frequencies (37\%). Other interneuron types display persistent firing at a still lower frequency (Sheffield et al., 2011). Consistent with this, we found that $<20 \%$ of FS PV basket cells displayed persistent firing. However, we found a high percentage ( $82 \%$ ) of Ivy cells displayed persistent firing, despite their location in or near SP (in contrast to the cells identified by Sheffield et al.). During persistent firing, a period of apparently self-sustained action potential firing, action potentials are believed to be initiated in the axon itself, backpropagating to the soma (Sheffield et al., 2011). The mechanism behind persistent firing is still uncertain, but it may rely on gap junctions (Sheffield et al., 2011). In retrospect, Ivy cells are a prime candidate for persistent firing, given that closely related NGF cells are gap junction coupled not only to other NGFs but also other cell types (Price et al., 2005; Simon et al., 2005; Zsiros and Maccaferri, 2005). Indeed, gap junctions between NGFs and other cell types provide a possible explanation for the occasional persistent firing observed in other cell populations.

We found that induction of persistent firing was inhibited by DAMGO. It has been shown previously that persistent firing is not affected by blocking $G_{A B A}, G A B A_{B}$, AMPA, and NMDA receptors (Sheffield et al., 2011), making it unlikely that this $\mu$ OR-mediated inhibition of persistent firing induction was a direct result of inhibition of GABA release. We also found that somatic hyperpolarization of the patched cell to match the membrane potential seen in the presence of DAMGO failed to mimic the effect of DAMGO on the induction of persistent firing. A possible interpretation of this finding is that the effects seen with DAMGO application were attributable to the hyperpolarization of many cells (rather than just the patched cell) actively participating in generating persistent firing. This interpretation is consistent with the concept of a network of gap-junctioned cells being involved in persistent firing. Alternatively, DAMGO may be directly inhibiting the axon. Indeed, we found that, with a greater level of hyperpolarization, which may invade the axon (Alle and Geiger, 2006; Shu et al., 2006), there was an increase in the number of action potentials required for persistent firing.

Finally, because NGF and Ivy cells express NPY, $\mu \mathrm{OR}-$ mediated inhibition of neurogliaform family interneurons may also decrease NPY release, with implications for neurogenesis (Eisch and Harburg, 2006; Howell et al., 2007), stress responses (Morgan et al., 2001; Kieffer and Gaveriaux-Ruff, 2002; Morgan et al., 2002, 2003), and epilepsy (Bellmann et al., 1991; Vezzani et al., 1999; Bacci et al., 2002). The $\mu$ OR system (both $\mu$ ORs and the endogenous ligand enkephalin) is altered in both epilepsy (Laorden et al., 1985; Gall, 1988; Gall et al., 1988; D'Intino et al., 2006; Rocha et al., 2007; Cuellar-Herrera et al., 2010) and Alzheimer's disease (Meilandt et al., 2008). In fact, it was shown that the increase in enkephalin in a model of Alzheimer's disease contributed to the cognitive difficulties associated with the disease (Meilandt et al., 2008). $\mu$ ORs on NGF and Ivy cells may represent a previously unidentified target in treating ailments as wide ranging as drug addiction, Alzheimer's disease, and epilepsy.

\section{References}

Alle H, Geiger JR (2006) Combined analog and action potential coding in hippocampal mossy fibers. Science 311:1290-1293.

Armstrong C, Szabadics J, Tamás G, Soltesz I (2011) Neurogliaform cells in the molecular layer of the dentate gyrus as feed-forward gammaaminobutyric acidergic modulators of entorhinal-hippocampal interplay. J Comp Neurol 519:1476-1491.

Ascoli GA, Alonso-Nanclares L, Anderson SA, Barrionuevo G, BenavidesPiccione R, Burkhalter A, Buzsáki G, Cauli B, Defelipe J, Fairén A, Feldmeyer D, Fishell G, Fregnac Y, Freund TF, Gardner D, Gardner EP, Goldberg JH, Helmstaedter M, Hestrin S, Karube F, et al. (2008) Petilla terminology: nomenclature of features of GABAergic interneurons of the cerebral cortex. Nat Rev Neurosci 9:557-568.

Bacci A, Huguenard JR, Prince DA (2002) Differential modulation of synaptic transmission by neuropeptide $\mathrm{Y}$ in rat neocortical neurons. Proc Natl Acad Sci U S A 99:17125-17130.

Bellmann R, Widmann R, Olenik C, Meyer DK, Maas D, Marksteiner J, Sperk G (1991) Enhanced rate of expression and biosynthesis of neuropeptide Y after kainic acid-induced seizures. J Neurochem 56:525-530.

Capogna M (2010) Neurogliaform cells and other interneurons of stratum lacunosum moleculare gate entorhinal-hippocampal dialogue. J Physiol 589:1875-1883.

Cuellar-Herrera M, Velasco AL, Velasco F, Chavez L, Orozco-Suarez S, Armagan G, Turunc E, Bojnik E, Yalcin A, Benyhe S, Borsodi A, AlonsoVanegas M, Rocha L (2010) Mu opioid receptor mRNA expression, binding, and functional coupling to G-proteins in human epileptic hippocampus. Hippocampus. Advance online publication. Retrieved September 8, 2011. doi:10.1002/hipo.20891.

D'Intino G, Vaccari F, Sivilia S, Scagliarini A, Gandini G, Giardino L, Calzà L (2006) A molecular study of hippocampus in dogs with convulsion during canine distemper virus encephalitis. Brain Res 1098:186-195.

Drake CT, Milner TA (1999) Mu opioid receptors are in somatodendritic and axonal compartments of GABAergic neurons in rat hippocampal formation. Brain Res 849:203-215.

Drake CT, Milner TA (2002) Mu opioid receptors are in discrete hippocampal interneuron subpopulations. Hippocampus 12:119-136.

Dvorak-Carbone H, Schuman EM (1999) Patterned activity in stratum lacunosum moleculare inhibits CA1 pyramidal neuron firing. J Neurophysiol 82:3213-3222.

Eisch AJ, Harburg GC (2006) Opiates, psychostimulants, and adult hippocampal neurogenesis: insights for addiction and stem cell biology. Hippocampus 16:271-286.

Empson RM, Heinemann U (1995) The perforant path projection to hippocampal area CA1 in the rat hippocampal-entorhinal cortex combined slice. J Physiol 484:707-720.

Férézou I, Hill EL, Cauli B, Gibelin N, Kaneko T, Rossier J, Lambolez B (2007) Extensive overlap of mu-opioid and nicotinic sensitivity in cortical interneurons. Cereb Cortex 17:1948-1957.

Freund TF, Buzsáki G (1996) Interneurons of the hippocampus. Hippocampus 6:347-470.

Fuentealba P, Begum R, Capogna M, Jinno S, Márton LF, Csicsvari J, Thomson A, Somogyi P, Klausberger T (2008) Ivy cells: a population of nitric-oxideproducing, slow-spiking GABAergic neurons and their involvement in hippocampal network activity. Neuron 57:917-929.

Fuentealba P, Klausberger T, Karayannis T, Suen WY, Huck J, Tomioka R, Rockland K, Capogna M, Studer M, Morales M, Somogyi P (2010) Expression of COUP-TFII nuclear receptor in restricted GABAergic neuronal populations in the adult rat hippocampus. J Neurosci 30:1595-1609.

Gall C (1988) Seizures induce dramatic and distinctly different changes in enkephalin, dynorphin, and CCK immunoreactivities in mouse hippocampal mossy fibers. J Neurosci 8:1852-1862.

Gall CM, Pico RM, Lauterborn JC (1988) Focal hippocampal lesions induce seizures and long-lasting changes in mossy fiber enkephalin and CCK immunoreactivity. Peptides 9 [Suppl 1]:79-84.

Glickfeld LL, Atallah BV, Scanziani M (2008) Complementary modulation of somatic inhibition by opioids and cannabinoids. J Neurosci 28:1824-1832

Handa BK, Land AC, Lord JA, Morgan BA, Rance MJ, Smith CF (1981) Analogues of beta-LPH61-64 possessing selective agonist activity at muopiate receptors. Eur J Pharmacol 70:531-540. 
Hefft S, Jonas P (2005) Asynchronous GABA release generates long-lasting inhibition at a hippocampal interneuron-principal neuron synapse. Nat Neurosci 8:1319-1328.

Hippenmeyer S, Vrieseling E, Sigrist M, Portmann T, Laengle C, Ladle DR, Arber S (2005) A developmental switch in the response of DRG neurons to ETS transcription factor signaling. PLoS Biol 3:e159.

Howell OW, Silva S, Scharfman HE, Sosunov AA, Zaben M, Shatya A, McKhann G 2nd, Herzog H, Laskowski A, Gray WP (2007) Neuropeptide Y is important for basal and seizure-induced precursor cell proliferation in the hippocampus. Neurobiol Dis 26:174-188.

Jamot L, Matthes HW, Simonin F, Kieffer BL, Roder JC (2003) Differential involvement of the mu and kappa opioid receptors in spatial learning. Genes Brain Behav 2:80-92.

Jin W, Chavkin C (1999) Mu opioids enhance mossy fiber synaptic transmission indirectly by reducing GABAB receptor activation. Brain Res 821:286-293.

Kieffer BL, Gavériaux-Ruff C (2002) Exploring the opioid system by gene knockout. Prog Neurobiol 66:285-306.

Kisvárday ZF, Gulyas A, Beroukas D, North JB, Chubb IW, Somogyi P (1990) Synapses, axonal and dendritic patterns of GABA-immunoreactive neurons in human cerebral cortex. Brain 113:793-812.

Klausberger T (2009) GABAergic interneurons targeting dendrites of pyramidal cells in the CAl area of the hippocampus. Eur J Neurosci 30: 947-957.

Krook-Magnuson E, Huntsman MM (2007) The transience of interneuron circuit diversity just "sped” up. Proc Natl Acad Sci U S A 104:1672316724.

Lafourcade CA, Alger BE (2008) Distinctions among GABAA and GABAB responses revealed by calcium channel antagonists, cannabinoids, opioids, and synaptic plasticity in rat hippocampus. Psychopharmacology (Berl) 198:539-549.

Laorden ML, Olaso MJ, Miralles FS, Puig MM (1985) Cerebrospinal fluid leucine-enkephalin-like levels in febrile convulsions. Methods Find Exp Clin Pharmacol 7:75-77.

Lee SH, Soltesz I (2011) Requirement for CB1 but not GABAB receptors in the cholecystokinin mediated inhibition of GABA release from cholecystokinin expressing basket cells. J Physiol 589:891-902.

Madisen L, Zwingman TA, Sunkin SM, Oh SW, Zariwala HA, Gu H, Ng LL, Palmiter RD, Hawrylycz MJ, Jones AR, Lein ES, Zeng H (2010) A robust and high-throughput Cre reporting and characterization system for the whole mouse brain. Nat Neurosci 13:133-140.

Mansouri FA, Motamedi F, Fathollahi Y, Atapour N, Semnanian S (1997) Augmentation of LTP induced by primed-bursts tetanic stimulation in hippocampal CA1 area of morphine dependent rats. Brain Res 769:119-124.

Matthes HW, Maldonado R, Simonin F, Valverde O, Slowe S, Kitchen I, Befort K, Dierich A, Le Meur M, Dollé P, Tzavara E, Hanoune J, Roques BP, Kieffer BL (1996) Loss of morphine-induced analgesia, reward effect and withdrawal symptoms in mice lacking the mu-opioid-receptor gene. Nature 383:819-823.

McDonald AJ, Culberson JL (1981) Neurons of the basolateral amygdala: a Golgi study in the opossum (Didelphis virginiana). Am J Anat 162: 327-342.

McQuiston AR (2008) Layer selective presynaptic modulation of excitatory inputs to hippocampal cornu Ammon 1 by mu-opioid receptor activation. Neuroscience 151:209-221.

McQuiston AR (2011) Mu opioid receptor activation normalizes temporoammonic pathway driven inhibition in hippocampal CA1. Neuropharmacology 60:472-479.

Meilandt WJ, Yu GQ, Chin J, Roberson ED, Palop JJ, Wu T, Scearce-Levie K, Mucke L (2008) Enkephalin elevations contribute to neuronal and behavioral impairments in a transgenic mouse model of Alzheimer's disease. J Neurosci 28:5007-5017.

Morgan CA 3rd, Wang S, Rasmusson A, Hazlett G, Anderson G, Charney DS (2001) Relationship among plasma cortisol, catecholamines, neuropeptide $\mathrm{Y}$, and human performance during exposure to uncontrollable stress. Psychosom Med 63:412-422.

Morgan CA 3rd, Rasmusson AM, Wang S, Hoyt G, Hauger RL, Hazlett G (2002) Neuropeptide-Y, cortisol, and subjective distress in humans exposed to acute stress: replication and extension of previous report. Biol Psychiatry 52:136-142.

Morgan CA 3rd, Rasmusson AM, Winters B, Hauger RL, Morgan J, Hazlett G, Southwick S (2003) Trauma exposure rather than posttraumatic stress disorder is associated with reduced baseline plasma neuropeptide-Y levels. Biol Psychiatry 54:1087-1091.

Neu A, Földy C, Soltesz I (2007) Postsynaptic origin of CB1-dependent tonic inhibition of GABA release at cholecystokinin-positive basket cell to pyramidal cell synapses in the CA1 region of the rat hippocampus. J Physiol 578:233-247.

Oláh S, Füle M, Komlósi G, Varga C, Báldi R, Barzó P, Tamás G (2009) Regulation of cortical microcircuits by unitary GABA-mediated volume transmission. Nature 461:1278-1281.

Pelton JT, Kazmierski W, Gulya K, Yamamura HI, Hruby VJ (1986) Design and synthesis of conformationally constrained somatostatin analogues with high potency and specificity for mu opioid receptors. J Med Chem 29:2370-2375.

Price CJ, Cauli B, Kovacs ER, Kulik A, Lambolez B, Shigemoto R, Capogna M (2005) Neurogliaform neurons form a novel inhibitory network in the hippocampal CA1 area. J Neurosci 25:6775-6786.

Raynor K, Kong H, Chen Y, Yasuda K, Yu L, Bell GI, Reisine T (1994) Pharmacological characterization of the cloned kappa-, delta-, and mu-opioid receptors. Mol Pharmacol 45:330-334.

Rocha L, Cuellar-Herrera M, Velasco M, Velasco F, Velasco AL, Jiménez F, Orozco-Suarez S, Borsodi A (2007) Opioid receptor binding in parahippocampus of patients with temporal lobe epilepsy: its association with the antiepileptic effects of subacute electrical stimulation. Seizure 16: 645-652.

Sheffield ME, Best TK, Mensh BD, Kath WL, Spruston N (2011) Slow integration leads to persistent action potential firing in distal axons of coupled interneurons. Nat Neurosci 14:200-207.

Shu Y, Hasenstaub A, Duque A, Yu Y, McCormick DA (2006) Modulation of intracortical synaptic potentials by presynaptic somatic membrane potential. Nature 441:761-765.

Simon A, Oláh S, Molnár G, Szabadics J, Tamás G (2005) Gap-junctional coupling between neurogliaform cells and various interneuron types in the neocortex. J Neurosci 25:6278-6285.

Soltesz I, Jones RS (1995) The direct perforant path input to CA1: excitatory or inhibitory? Hippocampus 5:101-103.

Svoboda KR, Adams CE, Lupica CR (1999) Opioid receptor subtype expression defines morphologically distinct classes of hippocampal interneurons. J Neurosci 19:85-95.

Szabadics J, Soltesz I (2009) Functional specificity of mossy fiber innervation of GABAergic cells in the hippocampus. J Neurosci 29:4239-4251.

Szabadics J, Tamas G, Soltesz I (2007) Different transmitter transients underlie presynaptic cell type specificity of GABAA,slow and GABAA,fast. Proc Natl Acad Sci U S A 104:14831-14836.

Szabadics J, Varga C, Brunner J, Chen K, Soltesz I (2010) Granule cells in the CA3 area. J Neurosci 30:8296-8307.

Tamás G, Lorincz A, Simon A, Szabadics J (2003) Identified sources and targets of slow inhibition in the neocortex. Science 299:1902-1905.

Tricoire L, Pelkey KA, Daw MI, Sousa VH, Miyoshi G, Jeffries B, Cauli B, Fishell G, McBain CJ (2010) Common origins of hippocampal Ivy and nitric oxide synthase expressing neurogliaform cells. J Neurosci 30:2165-2176.

van den Pol AN, Yao Y, Fu LY, Foo K, Huang H, Coppari R, Lowell BB, Broberger C (2009) Neuromedin B and gastrin-releasing peptide excite arcuate nucleus neuropeptide $\mathrm{Y}$ neurons in a novel transgenic mouse expressing strong Renilla green fluorescent protein in NPY neurons. J Neurosci 29:4622-4639.

Vezzani A, Sperk G, Colmers WF (1999) Neuropeptide Y: emerging evidence for a functional role in seizure modulation. Trends Neurosci 22:25-30.

Wagner JJ, Etemad LR, Thompson AM (2001) Opioid-mediated facilitation of long-term depression in rat hippocampus. J Pharmacol Exp Ther 296: $776-781$.

Weiss T, Veh RW (2011) Morphological and electrophysiological characteristics of neurons within identified subnuclei of the lateral habenula in rat brain slices. Neuroscience 172:74-93.

Williams TJ, Torres-Reveron A, Chapleau JD, Milner TA (2011) Hormonal regulation of delta opioid receptor immunoreactivity in interneurons and pyramidal cells in the rat hippocampus. Neurobiol Learn Mem 95: 206-220

Zsiros V, Maccaferri G (2005) Electrical coupling between interneurons with different excitable properties in the stratum lacunosum-moleculare of the juvenile CA1 rat hippocampus. J Neurosci 25:8686-8695. 